\title{
Eosinophil secretion of granule-derived cytokines
}

\author{
Lisa A. Spencer ${ }^{1}$, Kennedy Bonjour ${ }^{2}$, Rossana C. N. Melo ${ }^{2 \dagger}$ and Peter F. Weller ${ }^{1 * \dagger}$ \\ Department of Medicine, Beth Israel Deaconess Medical Center, Harvard Medical School, Boston, MA, USA \\ ${ }^{2}$ Laboratory of Cellular Biology, Department of Biology, Federal University of Juiz de Fora (UFJF), Juiz de Fora, Brazil
}

Edited by:

Paige Lacy, University of Alberta,

Canada

Reviewed by:

Roma Sehmi, McMaster University,

Canada

Nives Zimmermann, Cincinnati

Children's Hospital, USA

*Correspondence:

Peter F. Weller, 330 Brookline

Avenue, E/CLS Rm 940, Boston, MA

02215, USA

e-mail:pweller@bidmc.harvard.edu

${ }^{\dagger}$ Rossana C. N. Melo and Peter F.

Weller have contributed equally to

this work.

\begin{abstract}
Eosinophils are tissue-dwelling leukocytes, present in the thymus, and gastrointestinal and genitourinary tracts of healthy individuals at baseline, and recruited, often in large numbers, to allergic inflammatory foci and sites of active tissue repair. The biological significance of eosinophils is vast and varied. In health, eosinophils support uterine and mammary gland development, and maintain bone marrow plasma cells and adipose tissue alternatively activated macrophages, while in response to tissue insult eosinophils function as inflammatory effector cells, and, in the wake of an inflammatory response, promote tissue regeneration, and wound healing. One common mechanism driving many of the diverse eosinophil functions is the regulated and differential secretion of a vast array of eosinophil-derived cytokines. Eosinophils are distinguished from most other leukocytes in that many, if not all, of the over three dozen eosinophil-derived cytokines are pre-synthesized and stored within intracellular granules, poised for very rapid, stimulus-induced secretion. Eosinophils engaged in cytokine secretion in situ utilize distinct pathways of cytokine release that include classical exocytosis, whereby granules themselves fuse with the plasma membrane and release their entire contents extracellularly; piecemeal degranulation, whereby granule-derived cytokines are selectively mobilized into vesicles that emerge from granules, traverse the cytoplasm and fuse with the plasma membrane to release discrete packets of cytokines; and eosinophil cytolysis, whereby intact granules are extruded from eosinophils, and deposited within tissues. In this latter scenario, extracellular granules can themselves function as stimulus-responsive secretory-competent organelles within the tissue. Here, we review the distinctive processes of differential secretion of eosinophil granule-derived cytokines.
\end{abstract}

Keywords: secretion, eosinophil, granule, degranulation, piecemeal degranulation, cytolysis, cytokine

\section{INTRODUCTION}

\section{EOSINOPHILS ARE DISTINGUISHED BY THEIR EOSIN-LOVING SPECIFIC GRANULES}

Paul Ehrlich's discovery of eosinophils in 1879 was based on the distinctive "eosin-loving" property of eosinophil intracellular granules. The characteristic dark pink punctate staining seen in standard hematoxylin and eosin (H\&E) preparations is due to the high cationic protein content of eosinophil granules reacting with the acid dye eosin (1). The most abundant (and most cationic) of the eosinophil granule-derived proteins is major basic protein (MBP), and it is MBP that forms the crystalline lattice structure of the eosinophil granule core, an identifying ultrastructural feature of eosinophils (Figure 1). Eosinophils store their hydrolytic enzymes and cationic granule proteins, including MBP, eosinophil cationic protein (ECP), eosinophil peroxidase (EPO), and eosinophil-derived neurotoxin (EDN), within the core and surrounding matrix of eosinophil specific granules (Figure 1), and it has been long appreciated that secretion of these granulederived proteins can exert toxic effects on parasites, microbes, and host tissue cells [reviewed in Ref. (2)].

More recently appreciated is that in addition to cationic proteins and hydrolytic enzymes, eosinophils are sources of numerous (over three dozen identified to date) cytokines and chemokines, with a range of biological functions $(3,4)$. It is now recognized that along with the cationic proteins, many, if not all, of these cytokines are stored within eosinophil specific granules, available for very rapid secretion without the need for de novo synthesis (5). A recent study demonstrated co-expression of at least seven immunomodulatory cytokines preformed within specific granules of human blood eosinophils (6), and a number of physiological stimuli have been identified that elicit differential secretion of granule-stored cytokines from eosinophils $(7-10)$. Therefore, it is fitting that the distinguishing morphological feature of eosinophils (i.e., their specific granules) should also represent a functional distinction for these cells.

\section{VAST ARRAY AND BIOLOGICAL RELEVANCE OF EOSINOPHIL GRANULE-DERIVED MEDIATORS AND MECHANISMS OF SECRETION}

With the growing awareness of the diverse repertoire of eosinophil granule-derived cytokines has come an evolution in understanding the varied roles eosinophils play in biology. Previously considered strictly end-stage effector cells in parasitic helminth infections and allergic diseases such as asthma, eosinophils, and their secreted products are now regarded as participants in organ development $(11,12)$, metabolism (13), maintaining (14-16) and/or recruiting (17) lymphocyte populations, anti-microbial (18-22) 


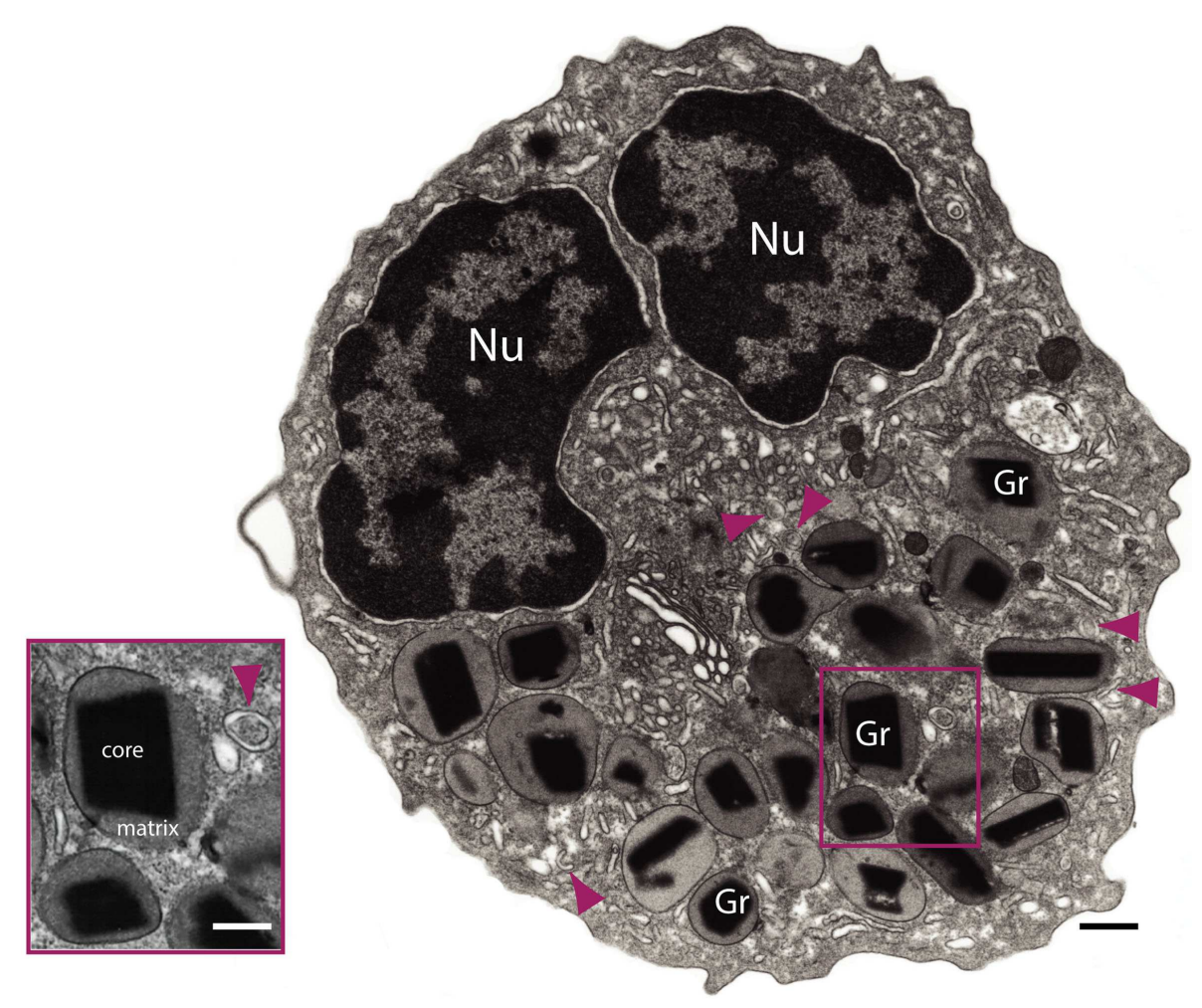

FIGURE 1 | Transmission electron microscopy of a human eosinophil. This cell is characterized by a major population of specific granules $(\mathrm{Gr})$ with a unique morphology - an internal often electron-dense crystalline core and an outer electron-lucent matrix surrounded by a delimiting trilaminar membrane. Note the typical bilobed nucleus (Nu) and large tubular carriers (arrowheads). The inset shows secretory granules and a tubular vesicle at higher magnification. Bars: $500 \mathrm{~nm} ; 300 \mathrm{~nm}$ (inset). and fungal (23-25) immunity, tissue repair and regeneration (2631), immunomodulation (32-37), and tumor immunity (38), and reviewed in Ref. (39).

How does the eosinophil accomplish the highly selective process of secretion of its granule-derived proteins? Basic Immunology textbooks often define degranulation from granulocytes such as eosinophils to occur by a process of classical exocytosis, whereby intracellular granules fuse with the plasma membrane and engage in a wholesale release of granule contents, or in more extreme instances compound exocytosis, whereby intracellular granules fuse together prior to fusion with the plasma membrane and release of their combined contents (Figure 2). Although degranulation via classic and compound exocytosis is observed upon interaction with very large metazoan parasites, in most other physiologically relevant scenarios eosinophils either (1) differentially and progressively secrete their granule-stored contents through a vesicle-dependent process termed piecemeal degranulation (PMD) or (2) deposit intact granules directly into the tissue through a distinctive mode of cell death, termed eosinophil cytolysis (Figure 2). To appreciate the extensiveness of PMD and cytolysis in tissue eosinophils in situ, we would refer the reader to Erjefalt et al. (40), and Saffari et al. (41), wherein using morphological criteria the authors quantify the number of tissue eosinophils undergoing PMD and/or cytolysis in association with allergic diseases (i.e., allergic rhinitis and asthma), eosinophilic esophagitis (EoE), or inflammatory bowel diseases (IBDs). In the former study, nearly all eosinophils from tissue sections of allergic disease patients exhibited evidence of PMD, and $27 \%$ of the eosinophils showed signs of cytolysis. In IBD samples, greater than $50 \%$ of the tissue eosinophils exhibited signs of PMD, while $14 \%$ were cytolytic (40). In the latter study, approximately $93 \%$ of esophageal eosinophils in EoE exhibited two or more features of degranulation, including loss of cell membrane integrity (marker of cytolysis), cytoplasmic vesiculation (PMD), or reversal of granule core staining (PMD). A total of $70 \%$ of esophageal eosinophils exhibited all three features (41). In the remainder of this manuscript, we will explore these two distinct modes of eosinophil secretion of granule-derived proteins.

\section{PIECEMEAL DEGRANULATION}

The process of PMD was first identified ultrastructurally through electron microscopy studies of mast cells, basophils, and eosinophils in the mid 1970s (42). PMD is characterized by a progressive emptying of granule contents without granule to plasma membrane fusions, rather PMD is accomplished by numerous spherical and tubular secretory vesicles that shuttle granulederived proteins from the granule to the plasma membrane for secretion. Within the past decade, biochemical and advanced microscopic techniques have enabled an unprecedented look into the process of PMD, and are revealing eosinophil intracellular 


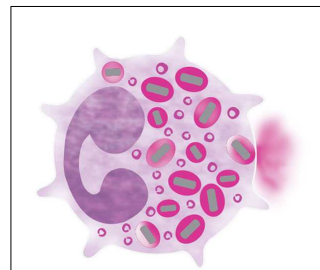

Classical exocytosis

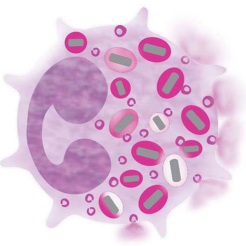

Piecemeal degranulation

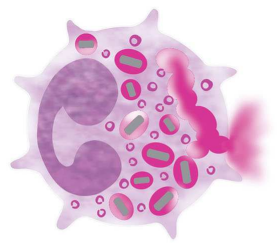

Compound exocytosis

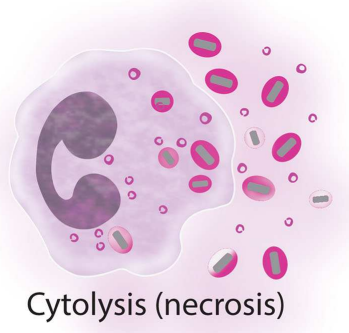

FIGURE 2 | Processes of eosinophil secretion. Eosinophils may secrete their granule proteins by classic exocytosis (individual granule fusion with the plasma membrane and release of the total granule content); compound exocytosis (intracellular granule-granule fusion before extracellular release); piecemeal degranulation (vesicular transport of small packets of materials from the secretory granules to the cell surface); and/or cytolysis (extracellular deposition of intact granules upon cell lysis). More than one process can be involved in inflammatory responses.

granules to be dynamic organelles, which undergo protein sorting and vesicle formation.

\section{EOSINOPHIL GRANULES ARE DYNAMIC INTRACELLULAR ORGANELLES}

Among the earliest ultrastructural indications of PMD are alterations within granules; the crystalline core may become less sharply defined, and variations in the electron density of the core and surrounding matrix occur, representative of disassembled matrices and cores and a reorganization of granule contents (Figure 3). Small spherical vesicles and elongated tubule carriers [eosinophil sombrero vesicles (EoSVs), discussed in the next section] are seen budding from emptying granules, and numbers of spherical vesicles and tubular carriers increase within the cell cytoplasm [(43) and Figures $\mathbf{4 A - C}$ ]. Immuno-electron microscopy using antibody Fab fragments conjugated to very small nano-gold particles confirm budding vesicles contain granulederived cytokines and cationic proteins [(43-45) and Figures 4DF]. Vesicles fuse with the plasma membrane and secrete cytokines extracellularly in discreet packets (Figures $\mathbf{4 G}, \mathbf{H}$ ).

Several lines of evidence support the conclusion that these vesicles are actually generated by and emerge from the granules themselves. Vesicular structures are apparent within emptying granules in the early stages of PMD, and treatment with the vesicular transport inhibitor brefeldin-A (BFA) inhibits the number of cytoplasmic vesicles (Figure 4B) and cytokine secretion by PMD, and causes depositions of membrano-lipid deposits within granules (43). Eosinophils undergoing PMD were further studied by dual-axis automated electron tomography, allowing for tracking of granule structures and content in three dimensions. Tomographic reconstructions demonstrate that granule contents within emptying granules are rearranged into intragranular vesiculotubular compartments and mobilized to the granule membrane. Moreover, both elongated tubular and small spherical vesicles containing granule contents were observed emerging directly from the eosinophil granules in tomographic reconstructions $(43,44,46)$.

\section{TUBULAR CARRIERS AND RECEPTOR-MEDIATED TRAFFICKING OF GRANULE-DERIVED CYTOKINES}

As noted above, eosinophils contain over three dozen preformed cytokines; most, if not all, of these cytokines are stored within intracellular granules. Eosinophil granule-derived cytokines are differentially secreted in response to exogenous stimulation, indicating that mechanisms must exist to sort granule-stored cytokines into granule-derived secretory vesicles. One mechanism has been described for the specific mobilization of IL4. Analysis of eosinophil lysates after subcellular fractionation revealed IL-4 receptor alpha chains (IL- $4 \mathrm{R} \alpha$ ) are enriched within granule- and vesicle-containing fractions. Upon stimulation of eosinophils with eotaxin-1, a chemokine known to elicit PMD of eosinophil granule-stored IL-4, complementary approaches based in immuno-electron microscopy and flow cytometry demonstrated granule-expressed IL-4R $\alpha$ is mobilized into secretory vesicles in parallel with IL-4 (47). Importantly, antibodies that compete with IL- 4 for binding to IL- $4 \mathrm{R} \alpha$ failed to detect vesiclemobilized IL- $4 \mathrm{R} \alpha$, suggesting that the receptor engages IL-4 during loading into secretory vesicles, and remains engaged while traversing the cytoplasm. This conclusion is supported by immuno-EM studies wherein IL-4 detected within secretory vesicles appears to be membrane-bound (47), in contrast to the free luminal expression pattern exhibited by vesicle-contained MBP (48) (Figures 4D-F). Vesicle-carried TGF- $\alpha$ also exhibits a membraneassociated expression pattern (49), and eosinophils express receptors for most (if not all) of the cytokines that they also store, suggesting that receptor-mediated chaperoning of cognate cytokines might be a universal method of regulating eosinophil-derived cytokine secretion.

This observation of receptor-mediated transport of granulederived cytokines also provides a function for the large tubular carriers (EoSVs) characteristic of eosinophils undergoing PMD. EoSVs represent a distinct vesicle population, distinguishable from smaller spherical vesicles by morphology and subcellular density. EoSVs observed within the cytoplasm by electron microscopy are viewed as elongated tubes, or when curled, may appear to take on the shape of a " $\mathrm{c}$ " or a donut ring (Figures $4 \mathrm{~A}, \mathrm{C}$ ). A key aspect of EoSV morphology is the large surface area:volume ratio, a conformation that is optimal for a receptor-mediated transport mechanism (44).

Although the number of cytoplasmic vesicles increases in eosinophils undergoing PMD, spherical vesicles and EoSVs are also observed in non-stimulated eosinophils (see Figure 1). For example, a substantial pool of MBP-loaded vesicles can be observed in intimate association with secretory granules in unstimulated eosinophils (48). It is unclear whether cargo-laden cytoplasmic vesicles are vestiges of a previous round of PMD, and/or whether eosinophils might utilize secretory vesicles as another, rapidly mobilizable, depot for intracellular cytokine storage. Of note, this 


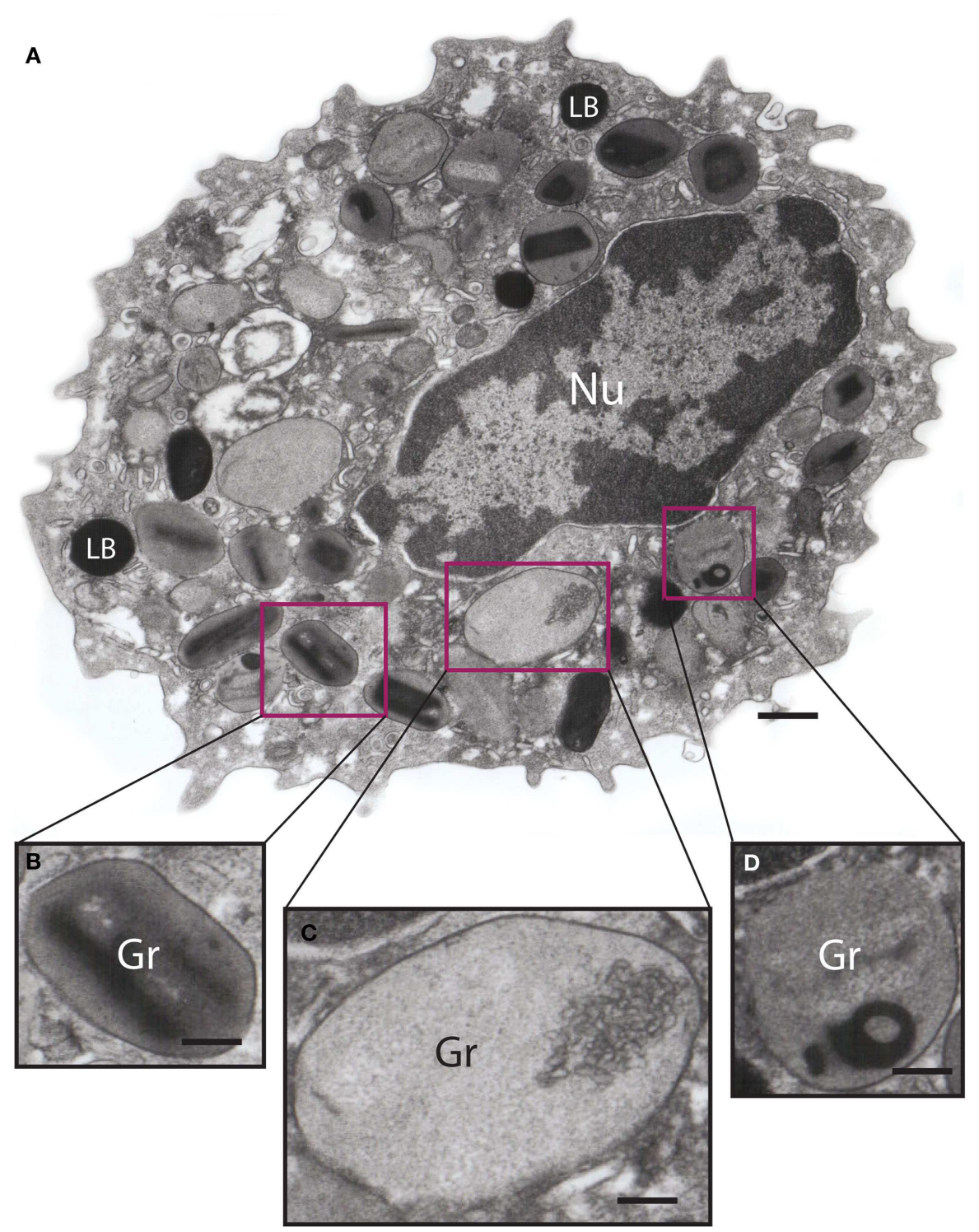

FIGURE 3 | Ultrastructure of an eotaxin-activated human eosinophil showing piecemeal degranulation (PMD). (A) After stimulation, specific granules (Gr) exhibit different degrees of emptying of their contents and morphological diversity indicative of PMD, such as (B) lucent areas in their cores, (C) enlargement and reduced electron density, and (D) residual cores. Eosinophils were isolated by negative selection from healthy donors, stimulated with eotaxin-1 for $1 \mathrm{~h}$, immediately fixed and prepared for transmission electron microscopy as before (43). Nu, nucleus; LB, lipid body. Scale bar: $500 \mathrm{~nm}$ (A); $170 \mathrm{~nm}$ (B-D). issue might be relevant to eosinophil postmortem function as well, as we will later see that EoSVs are released along with cell-free granules from cytolytic eosinophils (see Cytolysis below).

\section{INTRACRINE REGULATION OF EOSINOPHIL PMD}

Despite large strides in delineating dynamic intragranule vesiculation and receptor-mediated cytokine sorting, how exogenous signals are transmitted to and decoded by intracellular granules remain unclear. Exposure of eosinophils to a number of physiological stimuli, such as chemotactic lipids and chemokines, cytokines (e.g., IL-3, IL-5, and GM-CSF), and complement components can result in their priming, effectively lowering the signaling threshold for inducing subsequent stimulus-induced cytokine secretion. Intracellular mechanisms that drive eosinophil priming upstream of enhanced secretion are not fully understood. However, insideout signaling that upregulates the expression, affinity, and/or valency of eosinophil-expressed integrins (e.g., $\alpha_{M} \beta_{2}$ ) appears to play a significant role [reviewed in Ref. (50)] and may be mediated through a pathway involving PKC $\beta I I-d e p e n d e n t$ phosphorylation of the actin bundling protein L-plastin (51).

In addition to a role for priming in eosinophil secretion, data suggest the existence of intracrine mediators that act on intracellular receptors, possibly expressed on granules. For example, eotaxin-1-induced secretion of IL-4 is dependent upon an 

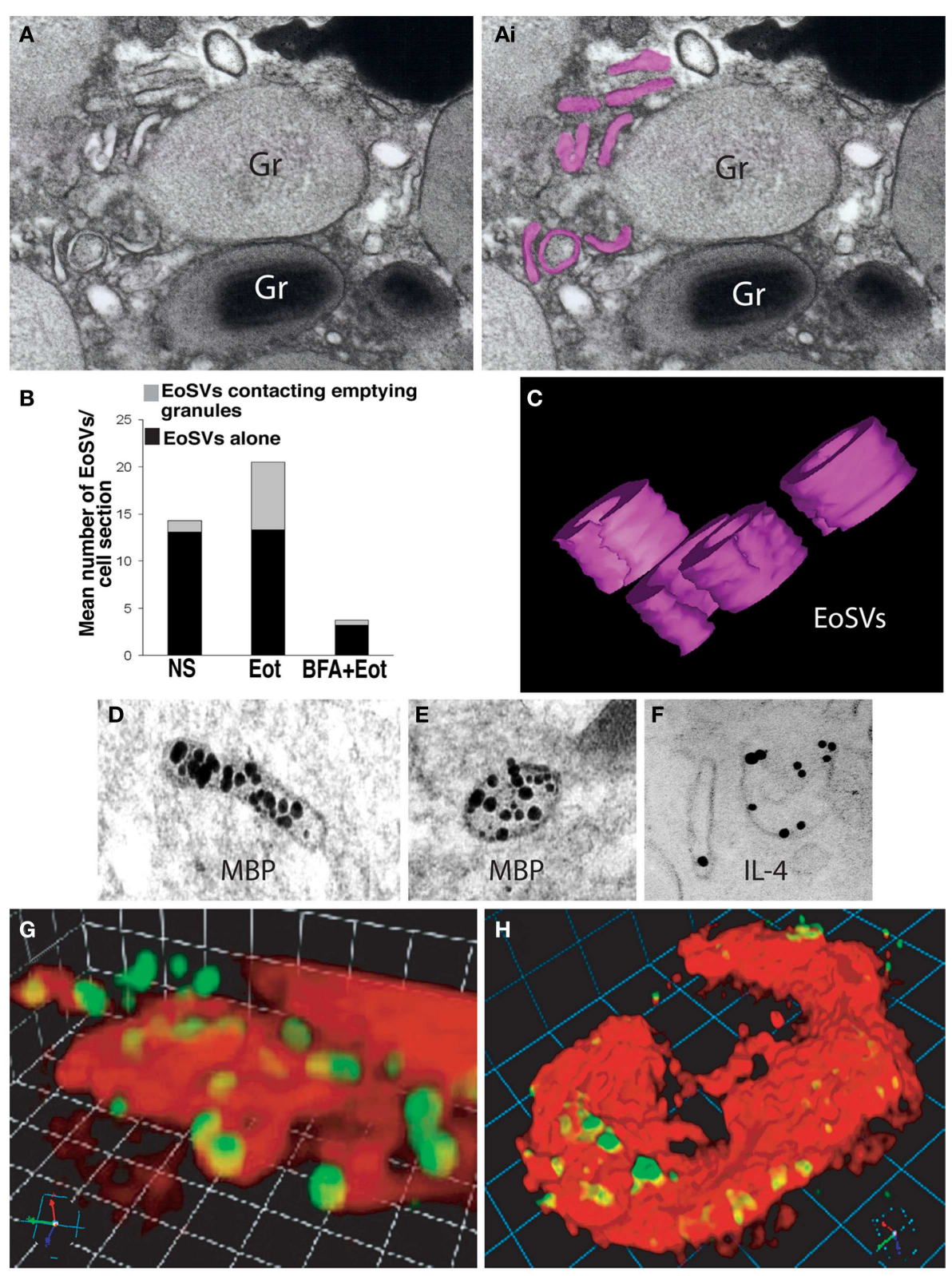

FIGURE 4 | Vesicular trafficking of granule-derived products from human eosinophils. (A) Eosinophil sombrero vesicles - EoSVs [highlighted in pink in (Ai)] are observed in the cytoplasm surrounding an emptying, enlarged secretory granule $(\mathrm{Gr})$. An intact granule $(\mathrm{Gr})$ with typical morphology is also observed. (B) Quantification of EoSV numbers revealed significant formation of these vesicles and association with granules undergoing release of their products, after eotaxin-1 (EOT) stimulation (45). Brefeldin-A (BFA) pretreatment suppressed all EoSV numbers dramatically $(P<0.05)$. NS, not stimulated. (C) Three-dimensional (3D) models obtained from electron tomographic analyses show EoSVs as curved tubular and open structures surrounding a cytoplasmic center. (D-F) As demonstrated by immunonanogold electron microscopy, major basic protein (MBP) $(\mathbf{D}, \mathbf{E})$ is transported within the EoSVs lumen, while IL-4 mobilization is associated with vesicle membrane (F). In (G,H), human blood eosinophils suspended in an anti-IL-4 capture antibody-containing agarose matrix were stimulated with eotaxin-1. 3D reconstructed images demonstrate released and captured IL-4 as focal fluorescent green spots at the outer surface of the cell membrane (stained in red). (B,F-H) were reprinted from Ref. (45) and (C-E) from Ref. (46) with permission. Scale bar: $250 \mathrm{~nm}$ (A); $150 \mathrm{~nm}$ (C-F); $4 \mu \mathrm{m}$ (G); $6 \mu \mathrm{m}$ (H). intracrine pathway involving the lipid mediator leukotriene $\mathrm{C}_{4}$ $\left(\mathrm{LTC}_{4}\right)$. Eotaxin-1 stimulation of eosinophils elicits the generation of $\mathrm{LTC}_{4}$ from intracellular lipid bodies; this $\mathrm{LTC}_{4}$, acting via an intracellular receptor, is necessary for subsequent IL-4 release
(52, 53). Eosinophil intracellular granules express leukotriene receptors on their outer granule membranes (54). Further studies are necessary to determine the specific intracellular target(s) of the LB-generated $\mathrm{LTC}_{4}$. 
In addition to the intracrine signaling mediators, cytoskeletal elements, GTPases, and membrane-associated proteins further coordinate granule and vesicle trafficking, and membrane fusions in PMD. For example, specific SNARE proteins [Soluble NSF Attachment Protein (SNAP) receptors] expressed by granule, vesicle, and plasma membranes within eosinophils co-ordinate membrane tethering, docking, and fusions [reviewed in Ref. (55)]. SNAREmediated membrane interactions are discussed in more detail in another article within this thematic issue.

\section{CYTOLYSIS}

Intriguingly, secretion of eosinophil granule-derived mediators does not necessarily cease upon cell death. The realization that eosinophils can undergo a distinct mode of cell death that results in the expulsion of intact intracellular granules has been a long time in coming. Structures resembling eosinophil cell-free granules appeared in drawings and stainings of asthmatic sputum as early as the 19th century, and in the early 20th century, free eosinophil granules were observed within pulmonary tissues from fatal asthma, a portion of which were attributed to eosinophil death [reviewed in Ref. (56)]. Importantly, in the late 1990s, Persson et al. helped to validate these earlier descriptions by demonstrating the existence of eosinophil cell-free granules in guinea pig trachea after provocation (i.e., epithelial shedding), using a methodology that could not be discounted on the basis of mechanical artifact, that of performing deep tissue staining of whole mounts (57). However, it is only within the last decade that cytolysis has been more widely appreciated as a physiologically significant mode of eosinophil activity, defined ultrastructurally, and evaluated within the context of specific diseases.

\section{EOSINOPHIL CYTOLYTIC CELL DEATH DEPOSITS GRANULES, BOTH FREE AND ASSOCIATED WITH NUCLEAR DNA NETS, INTO SURROUNDING TISSUE}

In addition to eosinophils exhibiting morphological evidence of PMD, micrographs of diseased tissues reveal eosinophils undergoing a cytolytic process of cell death morphologically distinct from both apoptosis and necrosis $(58,59)$. In contrast to the chromatin condensation and fragmentation of apoptotic nuclei, cytolytic eosinophils are characterized by dissolution of the nuclear membrane and DNA de-condensing into the surrounding cytoplasm (Figure 5). Membrane blebbing characteristic of necrotic cells also does not occur, rather cytolytic eosinophils are typified by a loss of membrane integrity, and release of intracellular contents, including eosinophil specific granules, into the surrounding tissue. Of note, EoSVs are also expelled from cytolytic eosinophils and deposited within the tissue alongside cell-free granules [Figure $\mathbf{5}$ and (41)]. Tissue-deposited, eosinophil cell-free granules are observed both within the spatial limits of the original cell and also scattered, independently or in clusters, outside of the confines of the originating cell.

The morphological sequelae associated with eosinophil cytolysis are elicited in vitro by a number of stimuli, including exposure to a $\mathrm{Ca}^{2+}$ ionophore, immobilized IgG or IgA, PMA, and GM-CSF or IL-5 in combination with PAF $(58,60,61)$. Closer examination of eosinophil death induced by cross-linking Siglec 8 (62) or exposure to Staphylococcus aureus supernatant (63) might implicate these as eosinophil cytolytic stimuli as well (64). By analyzing eosinophils undergoing cytolytic cell death in vitro induced by the calcium ionophore A23187, Ueki et al. recently reported a sequence of events that included, chronologically (1) alterations in nuclear shape and density, (2) expulsion of single or small clusters of granules from the cell, (3) decondensation of nuclear contents into the cytoplasm, and (4) loss of membrane integrity, accompanied by the release of single granules or granule clusters (58).

Ueki et al. also demonstrated that under these conditions, eosinophil cytolysis was accompanied by extrusions of nuclear DNA nets. Cell-free granules liberated from cytolytic eosinophils were observed both incorporated into the DNA net-like lattices, and also standing alone as DNA-free granule clusters (58). One might speculate that this so-called "DNA trap cell death" serves a protective function by bringing the anti-microbial power of eosinophil granule-derived proteins into close proximity to pathogens immobilized by a DNA trap. Of note, eosinophil cytolytic DNA trap cell death is reminiscent of the anti-microbial DNA traps described by Yousefi et al. (22) and Morshed et al. (65), wherein mitochondrial DNA is catapulted from live eosinophils along with granule-derived proteins (i.e., ECP and MBP), forming extracellular nets with demonstrated microbicidal functions. However, two important distinctions exist between the DNA nets elicited through eosinophil cytolytic death and the DNA traps described by Yousefi and Morshed. First, in contrast to eosinophil cytolysis-generated nets, the DNA traps described by Yousefi and Morshed emerge from eosinophils that remain viable. Second, the origin of the catapulted DNA in the latter case is mitochondrial, while cytolytic eosinophils extrude DNA nets of nuclear origin. Stimuli causing the expulsion of mitochondrial DNA traps from viable eosinophils include brief stimulation of IL-5-, or IFN- $\gamma$ primed eosinophils with LPS, C5a, or eotaxin (22), or stimulation of non-primed eosinophils with TSLP (65). It has yet to be seen how, if at all, the processes of DNA net extrusion from cytolytic eosinophils and the expulsion of mitochondrial DNA nets from viable eosinophils might relate to one another.

\section{SOME EOSINOPHIL GRANULES EXTRUDED FROM CYTOLYTIC EOSINOPHILS REMAIN SECRETORY-COMPETENT ORGANELLES}

One might predict that the consequence of extracellular granule release through eosinophil cytolysis, whether in association with or distinct from DNA nets, would be the continued capacity of eosinophils to deliver their granule contents postmortem. Micrographs of diseased tissues reveal eosinophil extracellular granules exhibiting varying degrees of dissolution of their delimiting membranes (56), suggesting some fraction of cell-free granules with compromised granule membrane integrity might "leak" their protein content within tissues. However, very recent studies now indicate that a portion of extracellularly deposited granules retain the integrity of an intact granule membrane (58). Moreover, extracellularly deposited granules express chemokine, cytokine, and lipid receptors on their outer membrane, such that the ligand binding domains are outwardly oriented and thereby available to interact with exogenous stimuli within the tissue [reviewed in Ref. (66)]. Neves et al. demonstrated outwardly oriented granuleexpressed receptors to be functional; in response to exogenous 


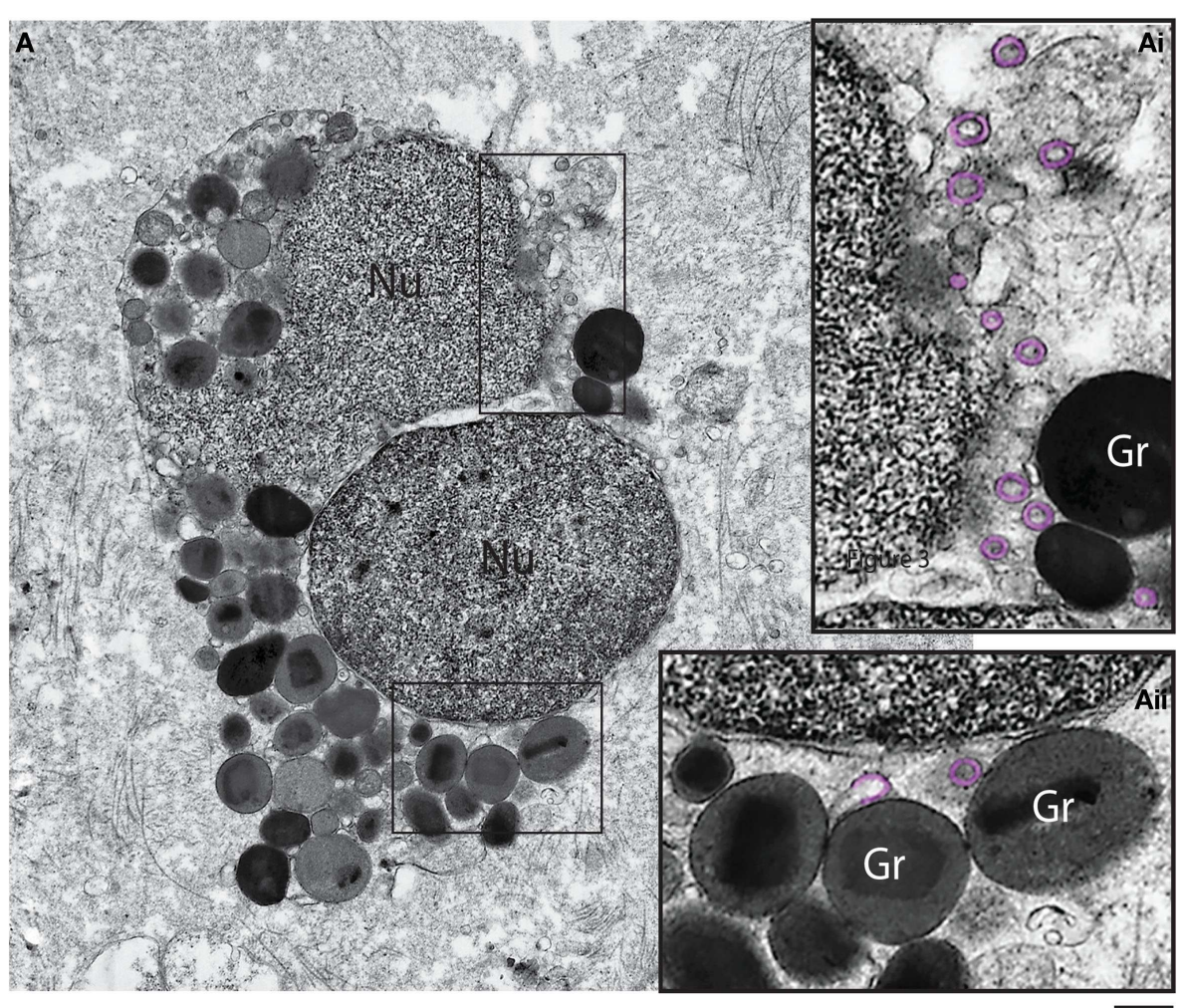

FIGURE 5 | Ultrastructure of a tissue human eosinophil undergoing cytolysis. Note the disintegrating nucleus ( $\mathrm{Nu}$ ) and extracellular free secretory granules $(\mathrm{Gr})$ in the surrounding tissue. (Ai, Aii) are boxed areas of (A) seen at higher magnification. Note the presence of free, intact eosinophil sombrero vesicles (EoSVs - highlighted in pink) in the tissue, after cell lysis. Tissue eosinophils were present in a biopsy performed on a patient with inflammatory bowel disease. Scale bar: $800 \mathrm{~nm}$ (A); $300 \mathrm{~nm}$ (Ai, Aii). eotaxin-1, IFN- $\gamma$, or leukotrienes, eosinophil cell-free granules exhibited kinase phosphorylation suggestive of activation of signal transduction pathways within the granule, and differentially released cationic proteins and cytokines in a stimulus dose- and kinase-dependent manner $(54,67)$. The implication of these findings is that cell-free granules liberated from cytolytic eosinophils function as stimulus-dependent, secretory-competent organelles within tissues.

\section{CONCLUDING REMARIKS AND FUTURE DIRECTIONS}

Biological functions of eosinophil-derived cytokines are a burgeoning field. Earlier views of eosinophils as strictly end-stage effectors in parasitic diseases are now being expanded to encompass a new understanding of eosinophils as multifunctional leukocytes participating in developmental, metabolic, and immune cell functions. Keeping pace with newly appreciated eosinophil functions in heath and disease is a growing understanding of the dynamic complexities involved in the stimulus-dependent, differential liberation of cytokines from eosinophil intracellular granules, both through the vesicular transport-based process of PMD in viable eosinophils, and postmortem through tissue-deposited eosinophil cell-free granules and EoSVs elicited from cytolytic eosinophils. These cutting edge mechanistic insights will be critical to the next generation of therapeutic approaches in targeting eosinophil-associated diseases, where one must now consider the manner by which eosinophils die when devising anti-eosinophil strategies, and must measure contributions of tissue-deposited eosinophil cell-free organelles when evaluating cytokine-mediated functions of eosinophils in situ in disease.

\section{ACKNOWLEDGMENTS}

This work was supported by the National Institute of Health (NIH) grants R37AI020241, R01AI022571 (Peter F. Weller), R01HL095699 (Lisa A. Spencer), Conselho Nacional de Desenvolvimento Cientifico e Tecnológico (CNPq, Brazil) grant 477475/2013-2 (Rossana C. N. Melo), and Fundação de Amparo a Pesquisa do Estado de Minas Gerais (FAPEMIG, Brazil) (Rossana C. N. Melo). We thank Ann M. Dvorak (BIDMC, Harvard Medical School) for supplying Figure 5.

\section{REFERENCES}

1. Spry CJF. Eosinophils: A Comprehensive Review and Guide to the Scientific and Medical Literature. Oxford: Oxford Medical Publications (1988).

2. Acharya KR, Ackerman SJ. Eosinophil granule proteins: form and function. JBiol Chem (2014) 289(25):17406-15. doi:10.1074/jbc.R113.546218

3. Wong DT, Weller PF, Galli SJ, Elovic A, Rand TH, Gallagher GT, et al. Human eosinophils express transforming growth factor alpha. J Exp Med (1990) 172(3):673-81. doi:10.1084/jem.172.3.673

4. Moqbel R, Coughlin JJ. Differential secretion of cytokines. Sci STKE (2006) 2006(338):e26. doi:10.1126/stke.3382006pe26

5. Beil WJ, Weller PF, Tzizik DM, Galli SJ, Dvorak AM. Ultrastructural immunogold localization of tumor necrosis factor-alpha to the matrix compartment 
of eosinophil secondary granules in patients with idiopathic hypereosinophilic syndrome. J Histochem Cytochem (1993) 41(11):1611-5. doi:10.1177/41.11. 8409368

6. Spencer LA, Szela CT, Perez SA, Kirchhoffer CL, Neves JS, Radke AL, et al. Human eosinophils constitutively express multiple Th1, Th2, and immunoregulatory cytokines that are secreted rapidly and differentially. J Leukoc Biol (2009) 85(1):117-23. doi:10.1189/jlb.0108058

7. Bandeira-Melo C, Sugiyama K, Woods LJ, Weller PF. Cutting edge: eotaxin elicits rapid vesicular transport-mediated release of preformed IL-4 from human eosinophils. J Immunol (2001) 166(8):4813-7. doi:10.4049/jimmunol.166.8. 4813

8. Miyamasu M, Hirai K, Takahashi Y, Iida M, Yamaguchi M, Koshino T, et al. Chemotactic agonists induce cytokine generation in eosinophils. J Immunol (1995) 154(3):1339-49.

9. Abu-Ghazaleh RI, Fujisawa T, Mestecky J, Kyle RA, Gleich GJ. IgA-induced eosinophil degranulation. J Immunol (1989) 142(7):2393-400.

10. Wong CK, Cheung PF, Ip WK, Lam CW. Intracellular signaling mechanisms regulating toll-like receptor-mediated activation of eosinophils. Am J Respir Cell Mol Biol (2007) 37(1):85-96. doi:10.1165/rcmb.2006-0457OC

11. Gouon-Evans V, Rothenberg ME, Pollard JW. Postnatal mammary gland development requires macrophages and eosinophils. Development (2000) 127(11):2269-82.

12. Robertson SA, Mau VJ, Hudson SN, Tremellen KP. Cytokine-leukocyte networks and the establishment of pregnancy. Am J Reprod Immunol (1997) 37(6):438-42. doi:10.1111/j.1600-0897.1997.tb00257.x

13. Wu D, Molofsky AB, Liang HE, Ricardo-Gonzalez RR, Jouihan HA, Bando JK, et al. Eosinophils sustain adipose alternatively activated macrophages associated with glucose homeostasis. Science (2011) 332(6026):243-7. doi:10.1126/science. 1201475

14. Wang HB, Weller PF. Pivotal advance: eosinophils mediate early alum adjuvantelicited B cell priming and IgM production. J Leukoc Biol (2008) 83(4):817-21. doi:10.1189/jlb.0607392

15. Chu VT, Frohlich A, Steinhauser G, Scheel T, Roch T, Fillatreau S, et al. Eosinophils are required for the maintenance of plasma cells in the bone marrow. Nat Immunol (2011) 12(2):151-9. doi:10.1038/ni.1981

16. Chu VT, Beller A, Rausch S, Strandmark J, Zanker M, Arbach O, et al. Eosinophils promote generation and maintenance of immunoglobulin-Aexpressing plasma cells and contribute to gut immune homeostasis. Immunity (2014) 40(4):582-93. doi:10.1016/j.immuni.2014.02.014

17. Jacobsen EA, Ochkur SI, Pero RS, Taranova AG, Protheroe CA, Colbert DC, et al. Allergic pulmonary inflammation in mice is dependent on eosinophilinduced recruitment of effector T cells. J Exp Med (2008) 205(3):699-710. doi:10.1084/jem.20071840

18. Lehrer RI, Szklarek D, Barton A, Ganz T, Hamann KJ, Gleich GJ. Antibacterial properties of eosinophil major basic protein and eosinophil cationic protein. J Immunol (1989) 142(12):4428-34.

19. Nakajima M, Hirakata M, Nittoh T, Ishihara K, Ohuchi K. Expression and purification of recombinant rat eosinophil-associated ribonucleases, homologues of human eosinophil cationic protein and eosinophil-derived neurotoxin, and their characterization. Int Arch Allergy Immunol (2001) 125(3):241-9. doi: $10.1159 / 000053822$

20. Persson T, Andersson P, Bodelsson M, Laurell M, Malm J, Egesten A. Bactericidal activity of human eosinophilic granulocytes against Escherichia coli. Infect Immun (2001) 69(6):3591-6. doi:10.1128/IAI.69.6.3591-3596.2001

21. Linch SN, Kelly AM, Danielson ET, Pero R, Lee JJ, Gold JA. Mouse eosinophils possess potent antibacterial properties in vivo. Infect Immun (2009) 77(11):4976-82. doi:10.1128/IAI.00306-09

22. Yousefi S, Gold JA, Andina N, Lee JJ, Kelly AM, Kozlowski E, et al. Catapultlike release of mitochondrial DNA by eosinophils contributes to antibacterial defense. Nat Med (2008) 14(9):949-53. doi:10.1038/nm.1855

23. Yoon J, Ponikau JU, Lawrence CB, Kita H. Innate antifungal immunity of human eosinophils mediated by a beta 2 integrin, CD11b. J Immunol (2008) 181(4):2907-15. doi:10.4049/jimmunol.181.4.2907

24. Matsuwaki Y, Wada K, White TA, Benson LM, Charlesworth MC, Checkel JL, et al. Recognition of fungal protease activities induces cellular activation and eosinophil-derived neurotoxin release in human eosinophils. J Immunol (2009) 183(10):6708-16. doi:10.4049/jimmunol.0901220
25. Inoue Y, Matsuwaki Y, Shin SH, Ponikau JU, Kita H. Nonpathogenic, environmental fungi induce activation and degranulation of human eosinophils. J Immunol (2005) 175(8):5439-47. doi:10.4049/jimmunol.175.8.5439

26. Todd R, Donoff BR, Chiang T, Chou MY, Elovic A, Gallagher GT, et al. The eosinophil as a cellular source of transforming growth factor alpha in healing cutaneous wounds. Am J Pathol (1991) 138(6):1307-13.

27. Aceves SS, Broide DH. Airway fibrosis and angiogenesis due to eosinophil trafficking in chronic asthma. Curr Mol Med (2008) 8(5):350-8. doi:10.2174/ 156652408785161023

28. Detoraki A, Granata F, Staibano S, Rossi FW, Marone G, Genovese A. Angiogenesis and lymphangiogenesis in bronchial asthma. Allergy (2010) 65(8):946-58. doi:10.1111/j.1398-9995.2010.02372.x

29. Puxeddu I, Alian A, Piliponsky AM, Ribatti D, Panet A, Levi-Schaffer F. Human peripheral blood eosinophils induce angiogenesis. Int J Biochem Cell Biol (2005) 37(3):628-36. doi:10.1016/j.biocel.2004.09.001

30. Hoshino M, Takahashi M, Aoike N. Expression of vascular endothelial growth factor, basic fibroblast growth factor, and angiogenin immunoreactivity in asthmatic airways and its relationship to angiogenesis. J Allergy Clin Immunol (2001) 107(2):295-301. doi:10.1067/mai.2001.115626

31. Hoshino M, Nakamura Y, Hamid QA. Gene expression of vascular endothelial growth factor and its receptors and angiogenesis in bronchial asthma. J Allergy Clin Immunol (2001) 107(6):1034-8. doi:10.1067/mai.2001.115626

32. Jacobsen EA, Zellner KR, Colbert D, Lee NA, Lee JJ. Eosinophils regulate dendritic cells and Th2 pulmonary immune responses following allergen provocation. J Immunol (2011) 187(11):6059-68. doi:10.4049/jimmunol.1102299

33. Voehringer D, Reese TA, Huang X, Shinkai K, Locksley RM. Type 2 immunity is controlled by IL-4/IL-13 expression in hematopoietic non-eosinophil cells of the innate immune system. J Exp Med (2006) 203(6):1435-46. doi:10.1084/jem. 20052448

34. Voehringer D, Shinkai K, Locksley RM. Type 2 immunity reflects orchestrated recruitment of cells committed to IL-4 production. Immunity (2004) 20(3):267-77. doi:10.1016/S1074-7613(04)00026-3

35. MacKenzie JR, Mattes J, Dent LA, Foster PS. Eosinophils promote allergic disease of the lung by regulating CD4(+) Th2 lymphocyte function. J Immunol (2001) 167(6):3146-55. doi:10.4049/jimmunol.167.6.3146

36. Shi HZ, Xiao CQ, Li CQ, Mo XY, Yang QL, Leng J, et al. Endobronchial eosinophils preferentially stimulate Thelper cell type 2 responses. Allergy (2004) 59(4):428-35. doi:10.1046/j.1398-9995.2003.00405.x

37. Yang D, Chen Q, Su SB, Zhang P, Kurosaka K, Caspi RR, et al. Eosinophilderived neurotoxin acts as an alarmin to activate the TLR2-MyD88 signal pathway in dendritic cells and enhances Th2 immune responses. J Exp Med (2008) 205(1):79-90. doi:10.1084/jem.20062027

38. Cormier SA, Taranova AG, Bedient C, Nguyen T, Protheroe C, Pero R, et al. Pivotal advance: eosinophil infiltration of solid tumors is an early and persistent inflammatory host response. J Leukoc Biol (2006) 79(6):1131-9. doi:10.1189/ jlb.0106027

39. Samoszuk M. Eosinophils and human cancer. Histol Histopathol (1997) 12(3):807-12.

40. Erjefalt JS, Greiff L, Andersson M, Adelroth E, Jeffery PK, Persson CG. Degranulation patterns of eosinophil granulocytes as determinants of eosinophil driven disease. Thorax (2001) 56(5):341-4. doi:10.1136/thorax.56.5.341

41. Saffari H, Hoffman LH, Peterson KA, Fang JC, Leiferman KM, Pease LF III, et al. Electron microscopy elucidates eosinophil degranulation patterns in patients with eosinophilic esophagitis. J Allergy Clin Immunol (2014) 133(6):1728-34e1. doi:10.1016/j.jaci.2013.11.024

42. Dvorak HF, Dvorak AM. Basophilic leucocytes: structure, function and role in disease. Clin Haematol (1975) 4(3):651-83.

43. Melo RCN, Perez SA, Spencer LA, Dvorak AM, Weller PF. Intragranular vesiculotubular compartments are involved in piecemeal degranulation by activated human eosinophils. Traffic (2005) 6(10):866-79. doi:10.1111/j.1600-0854.2005. 00322.x

44. Melo RCN, Spencer LA, Dvorak AM, Weller PF. Mechanisms of eosinophil secretion: large vesiculotubular carriers mediate transport and release of granulederived cytokines and other proteins. J Leukoc Biol (2008) 83(2):229-36. doi:10.1189/jlb.0707503

45. Melo RCN, Spencer LA, Perez SA, Ghiran I, Dvorak AM, Weller PF. Human eosinophils secrete preformed, granule-stored interleukin-4 through distinct 
vesicular compartments. Traffic (2005) 6(11):1047-57. doi:10.1111/j.16000854.2005.00344.x

46. Melo RCN, Dvorak AM, Weller PF. Electron tomography and immunonanogold electron microscopy for investigating intracellular trafficking and secretion in human eosinophils. J Cell Mol Med (2008) 12(4):1416-9. doi:10.1111/j.15824934.2008.00346.x

47. Spencer LA, Melo RCN, Perez SA, Bafford SP, Dvorak AM, Weller PF. Cytokine receptor-mediated trafficking of preformed IL-4 in eosinophils identifies an innate immune mechanism of cytokine secretion. Proc Natl Acad Sci U S A (2006) 103(9):3333-8. doi:10.1073/pnas.0508946103

48. Melo RCN, Spencer LA, Perez SA, Neves JS, Bafford SP, Morgan ES, et al. Vesiclemediated secretion of human eosinophil granule-derived major basic protein. Lab Invest (2009) 89(7):769-81. doi:10.1038/labinvest.2009.40

49. Egesten A, Calafat J, Knol EF, Janssen H, Walz TM. Subcellular localization of transforming growth factor-alpha in human eosinophil granulocytes. Blood (1996) 87(9):3910-8.

50. Koenderman L. Priming: a critical step in the control of eosinophil activation. In: Lee JHF, Rosenberg HF, editors. Eosinophils in Health and Disease. Boston, MA: Elsevier (2013). p. 170-8.

51. Pazdrak K, Young TW, Straub C, Stafford S, Kurosky A. Priming of eosinophils by GM-CSF is mediated by protein kinase CbetaII-phosphorylated L-plastin. J Immunol (2011) 186(11):6485-96. doi:10.4049/jimmunol.1001868

52. Bandeira-Melo C, Hall JC, Penrose JF, Weller PF. Cysteinyl leukotrienes induce IL-4 release from cord blood-derived human eosinophils. JAllergy Clin Immunol (2002) 109(6):975-9. doi:10.1067/mai.2002.124269

53. Bandeira-Melo C, Woods LJ, Phoofolo M, Weller PF. Intracrine cysteinyl leukotriene receptor-mediated signaling of eosinophil vesicular transportmediated interleukin-4 secretion. J Exp Med (2002) 196(6):841-50. doi:10.1084/ jem.20020516

54. Neves JS, Radke AL, Weller PF. Cysteinyl leukotrienes acting via granule membrane expressed receptors elicit secretion from within cell-free human eosinophil granules. J Allergy Clin Immunol (2010) 125(2):477-82. doi:10.1016/j.jaci.2009. 11.029

55. Lacy P, Moqbel R. Signaling and degranulation. In: Lee JJ, Rosenberg HF, editors. Eosinophils in Health and Disease. Boston, MA: Elsevier (2013). p. 206-19.

56. Persson CG, Erjefalt JS. "Ultimate activation" of eosinophils in vivo: lysis and release of clusters of free eosinophil granules (Cfegs). Thorax (1997) 52(6):569-74. doi:10.1136/thx.52.6.569

57. Erjefalt JS, Sundler F, Persson CG. Eosinophils, neutrophils, and venular gaps in the airway mucosa at epithelial removal-restitution. Am J Respir Crit Care Med (1996) 153(5):1666-74. doi:10.1164/ajrccm.153.5.8630618

58. Ueki S, Melo RCN, Ghiran I, Spencer LA, Dvorak AM, Weller PF. Eosinophil extracellular DNA trap cell death mediates lytic release of free secretioncompetent eosinophil granules in humans. Blood (2013) 121(11):2074-83. doi:10.1182/blood-2012-05-432088
59. Cheng JF, Ott NL, Peterson EA, George TJ, Hukee MJ, Gleich GJ, et al. Dermal eosinophils in atopic dermatitis undergo cytolytic degeneration. J Allergy Clin Immunol (1997) 99(5):683-92. doi:10.1016/S0091-6749(97)70031-9

60. Weiler CR, Kita H, Hukee M, Gleich GJ. Eosinophil viability during immunoglobulin-induced degranulation. J Leukoc Biol (1996) 60(4):493-501.

61. Fukuda T, Ackerman SJ, Reed CE, Peters MS, Dunnette SL, Gleich GJ. Calcium ionophore A23187 calcium-dependent cytolytic degranulation in human eosinophils. J Immunol (1985) 135(2):1349-56.

62. Kano G, Almanan M, Bochner BS, Zimmermann N. Mechanism of Siglec8-mediated cell death in IL-5-activated eosinophils: role for reactive oxygen species-enhanced MEK/ERK activation. J Allergy Clin Immunol (2013) 132(2):437-45. doi:10.1016/j.jaci.2013.03.024

63. Prince LR, Graham KJ, Connolly J, Anwar S, Ridley R, Sabroe I, et al. Staphylococcus aureus induces eosinophil cell death mediated by alpha-hemolysin. PLoS One (2012) 7(2):e31506. doi:10.1371/journal.pone.0031506

64. Persson C, Uller L. Theirs but to die and do: primary lysis of eosinophils and free eosinophil granules in asthma. Am J Respir Crit Care Med (2014) 189(6):628-33. doi:10.1164/rccm.201311-2069OE

65. Morshed M, Yousefi S, Stockle C, Simon HU, Simon D. Thymic stromal lymphopoietin stimulates the formation of eosinophil extracellular traps. Allergy (2012) 67(9):1127-37. doi:10.1111/j.1398-9995.2012.02868.x

66. Neves JS, Weller PF. Functional extracellular eosinophil granules: novel implications in eosinophil immunobiology. Curr Opin Immunol (2009) 21(6):694-9. doi:10.1016/j.coi.2009.07.011

67. Neves JS, Perez SA, Spencer LA, Melo RCN, Reynolds L, Ghiran I, et al. Eosinophil granules function extracellularly as receptor-mediated secretory organelles. Proc Natl Acad Sci U S A (2008) 105(47):18478-83. doi:10.1073/ pnas. 0804547105

Conflict of Interest Statement: The authors declare that the research was conducted in the absence of any commercial or financial relationships that could be construed as a potential conflict of interest.

Received: 07 August 2014; accepted: 23 September 2014; published online: 27 October 2014.

Citation: Spencer LA, Bonjour K, Melo RCN and Weller PF (2014) Eosinophil secretion of granule-derived cytokines. Front. Immunol. 5:496. doi: 10.3389/fimmu.2014.00496 This article was submitted to Molecular Innate Immunity, a section of the journal Frontiers in Immunology.

Copyright $\odot 2014$ Spencer, Bonjour, Melo and Weller. This is an open-access article distributed under the terms of the Creative Commons Attribution License (CC BY). The use, distribution or reproduction in other forums is permitted, provided the original author(s) or licensor are credited and that the original publication in this journal is cited, in accordance with accepted academic practice. No use, distribution or reproduction is permitted which does not comply with these terms. 